\begin{tabular}{|l|c|c|}
\hline \multicolumn{2}{|c|}{ DJS Vol. 38 (2017) 234-247 } \\
\hline 1969 & Delta Journal of Science & \\
\hline
\end{tabular}

\title{
Diatom analysis of Edku Lake sediments to assess the Late Holocene environmental changes in northern Egypt
}

\author{
Abdelfattah A. Zalat, Hamza M. Khalil, Ali S. Ali and Seham A. El Nagar \\ Geology Department, Faculty of Science, Tanta University, 31527 Tanta, Egypt \\ (E-mail:abzalat@science.tanta.edu.eg)
}

\begin{abstract}
Quantitative and qualitative diatom analyses from the Edku Lake core sediments were used to assess the environmental history of the lake during the Late Holocene. A total of 128 diatom species and varieties were identified from 118 samples representing of four short cores obtained from the lake. The topmost samples represent the recent time are dominant by diatom taxa than that recorded in the lowered cores samples. Detailed diatom investigation indicated a considerable variation in the composition and distribution of the diatom taxa among the studied cores. The non-planktonic epiphytic taxa Cocconeis placentula, Epithemia sorex, Epithemia adnata and the benthic forms Navicula aegyptiaca, Campylodiscus biocostatus and Campylodiscus clypeus were the most dominant species in the core sediments, which mainly reflect slightly brackish, alkaline, eutrophic shallow lake condition during the time of deposition. Multivariate statistical analysis included hierarchical ascending clustering and Detrended correspondence analyses were used to identify ecological groups of diatoms. The results distinguished six ecological groups that reflect changes in the water quality, water salinity, lake-level, $\mathrm{pH}$ and eutrophication of the lake, which in turn may related to climatic changes and anthropogenic impacts.
\end{abstract}

Key words: diatom analysis, Edku Lake, core sediments, Late Holocene, environmental changes

\section{Introduction:}

Diatoms are single-celled photosynthetic microalgae which are found in all aquatic habitats from marine to fresh water environments. They respond rapidly to environmental changes and their siliceous frustules are usually well preserved in the lake sediments. Therefore, they can provide sensitive high-resolution records of several environmental variables such as paleosalinity, paleo-temperature, paleocurrents, alkalinity, eutrophication and lake level changes, which are mainly associated with fluctuations in climatic conditions such as precipitation and evaporation rates. Thus, diatoms have been used as proxy indicators to reconstruct the paleoenvironmental and climatic changes through the Holocene on every continent (Pienitz et al. 1995; Fritz et al. 1999; Korhola et al. 2000; Yang \& Duthie 1995; Moser et al. 2000; Kuwae et al. 2004; Bradbury et al. 2004; Stager et al. 2005; Bracco et al. 2005; Zalat \& Vildary 2005, 2007; Zalat 2015; Smol \& Stoermer 2010; Wolin \& Stone 2010; Larid et al. 2011).
The present work is focused to study Edku Lake, which located west of the Rosetta branch of the River Nile. This lake is considered the third largest wetland area in northern delta of Egypt. It's a typical delta edge lagoon, which was subjected to a gradual shrinkage during the past few decades due to land reclamation and transformation of significant parts of the lake to fish farms, particularly along the southern regions. The lake history displayed steady reduction from $200 \mathrm{~km}^{2}$ before the $1940 \mathrm{~s}$ to some $150 \mathrm{~km}^{2}$ in the 1950s to the present $62 \mathrm{~km}^{2}$ (Khalil et al. 2008). It is estimated that a reduction of some $30 \%$ of the lake area has occurred in the last 20 years by the development of drainage and irrigation schemes in the eastern portion.

Several studies has been carried out on the hydrography, pollution, chemical and biological characteristics of Edku Lake water and sediments (e.g. Kinawy, 1974; Banoub, 1979, 1983; Soliman, 1983; Hemeda 1988, Saad, 1976, 1978a, b; 1988; Moussa and ElSayed, 1990; Shridah, 1992;Ibrahim 1994, Abdel-Moati and 
El-Sammak, 1996; Gharib and Soliman, 1998; Gharib, 1999; Shakweer et al., 1998; Nour El-Din, 2000; Shata 2000, Zaghloul and Hussein 2000, Edlund and Carman 2001, Okbah and Gohary 2002, Kim et al. 2003, Shakweer 2006, Khalil 2007, Badr and Hussin 2010). Most of these studies concerned with the phytoplankton distribution, water quality and pollution effect on biological conditions. These studies are concluded that the Edku Lake is suffered from a high level of eutrophication due to the heavy load of nutrients from different drains. Domestic, agricultural sewage and industrial contamination of the lake water are the most dangerous aspects, since it results in high load of allochtonous organic matter and nutrients which might seriously contaminate the natural habitat. However, none of the published studies had concerned with the diatom assemblages that preserved in the lake sediments during the last decades. The present paper aims to shed light on the distribution of diatom assemblages in the lake sediments to explain the environmental changes that occurred during the Late Holocene.

\section{Lake description}

Lake Edku is a coastal lagoon in the eastern Mediterranean. It is a shallow, eutrophic, brackish, coastal basin of about $17 \mathrm{~km}$ long in the east-west direction, 11 $\mathrm{km}$ width at its widest part and about $5 \mathrm{~km}$ at the narrowest part. The lake is situated in the north-western part of the Nile Delta, $18 \mathrm{Km}$ west of the Rosetta branch of the River Nile and about $40 \mathrm{~km}$ northeast of Alexandria, between longitude $30^{\circ} 8^{\prime} 30^{\prime \prime}$ and $30^{\circ} 23^{\prime} \quad 00^{\prime \prime} \mathrm{E}$ and latitude $31^{\circ} 10^{\prime} 00^{\prime \prime}$ and $31^{\circ} 18^{\prime} 00^{\prime \prime} \mathrm{N}$ (Fig. 1). The lake is surrounded by a productive agriculture to the south, by ongoing land reclamation activities to the east side and by housing and industry to the west side. The lake margin is essentially straight along its northern border, while the eastern margin is bounded by Edku drain. The total surface area of the lake is about $62.5 \mathrm{~km}^{2}$ of which $22 \mathrm{~km}^{2}$ is open water, whereas the remaining area of about $42.7 \mathrm{~km}^{2}$ is either covered by aquatic vegetation or occupied by island and islets. The open water area represents about 35\% almost one third of the total area of the lake (Moufaddal et al. 2008). The lake level fluctuates between 50 and $150 \mathrm{~cm}$ and the deepest part is found at its center of open area. The shallower areas are restricted to the lake margins, around the islands and El- Maadiya area with depth ranges between 30 and $50 \mathrm{~cm}$. The lake is separated from the Mediterranean Sea through a sand barrier that is occasionally inhabited with salt marshes, salinas and high dunes. But it is communicated with the sea at the village of Maadiya near to its northwestern end through $20 \mathrm{~m}$ wide, $100 \mathrm{~m}$ long and 2-meter deep channel called "El-Boughaz El-Maadyia".

The water of the lake is not homogenous in appearance, varying from clear to very turbid with anoxic water smelling of hydrogen sulphide in some parts of the lake. Lake waters are brackish, with fresh discharging mainly from the Edku drain, which is located at the eastern part of the lake. This large drain, a branch of El
Mahmudiya canal, collects drainage water from the Beheirah Province watershed. However, the sewage and industrial wastes, discharged into the sea from the industrial complex along the Abu Qir coast via El Tabia pumping station, west of El Maadyah, may at times enter the lagoon through the inlet at El Maadyah (Saad, 1978a). Therefore, the lake is represented by three habitats: (1) drainage habitat; (2) lake-sea connection, which is considered the transitional zone between the lake and the Mediterranean Sea; and (3) the body of lake habitat. The bottom sediments of the lake are composed mainly of clay and to a less extent of sand. The percentage of clay increases towards the southern and eastern areas. Abundantly of Mollusks shells and calcareous remains as well as barnacles and tubeworms are widely distributed all over the lake bottom.

The occurrence of several small islands divides the lake into a smaller western district and a larger one comprising the central and eastern parts where the outlets of Kom Belag drain at the east and Bersik at the south central part of this lake. Therefore the eastern and southern areas are heavily populated with aquatic vegetation. The eastern side of the lake is delimited by El-Khairy Drain, which separates a large reclaimed cultivated land that was previously a part of Lake Edku. The southern part of the lake is characterized by an excessive growth of hydrophytes, and large quantities of the floating, aerial and submerged plants covering nearly $50 \%$ of the lake surface area. The lake margins are also extensively vegetated, mainly by Phragmites and Typha. These plants are frequent on the islands and everywhere water hyacinth (Eichhornia crassipes) is proliferating (Ramdani et al. 2001).

\section{Materials and Methods}

The present work is based on 118 samples obtained from four short cores which are drilled in the lake using $50 \mathrm{~mm}$ diameter piston-corer during April, 2013. The locations of the sites were selected to cover a gradient of environmental variables that may be important to water quality. The investigated samples obtained from the cores at $3 \mathrm{~cm}$ intervals, which are composed mainly of greenish gray mud and sandy mud, and some samples contain mollusk shells. During the sampling time, the following limnological variables were measured: water depth, surface water temperature, dissolved oxygen (DO), water $\mathrm{pH}$ was reported by a glass electrode $\mathrm{pH}$ meter, and electrical conductivity was measured using electric conductimeter. Sediment samples were dried overnight at $80{ }^{\circ} \mathrm{C}$, and diatoms were extracted from one gram of dry sediment according to technique proposed by Zalat (2002). The dry subsample is boiling in $20 \% \mathrm{HCL}$ in order to remove the carbonate fraction, followed by rinsing in distilled water, then treating with cold 30\% hydrogen peroxide to oxidize organic matter. Coarse particles were removed by further decantation (settling for $5 \mathrm{~s}$ ). Finally, one drop of the final suspension was dried onto cover slips, then mounted onto slides using Canada Balsam ${ }^{\circledR}$ 
$($ R.I $=1.74)$. The diatom slides are now part of the permanent diatom collection of the Geological Department, Tanta University, Egypt.

Diatom identification was done using a Carl Zeiss photomicroscope with phase contrast and an oil immersion objective at $1200 x$. Diatom valves were counted along 10 random transects across the slide. In diatom-poor samples, 


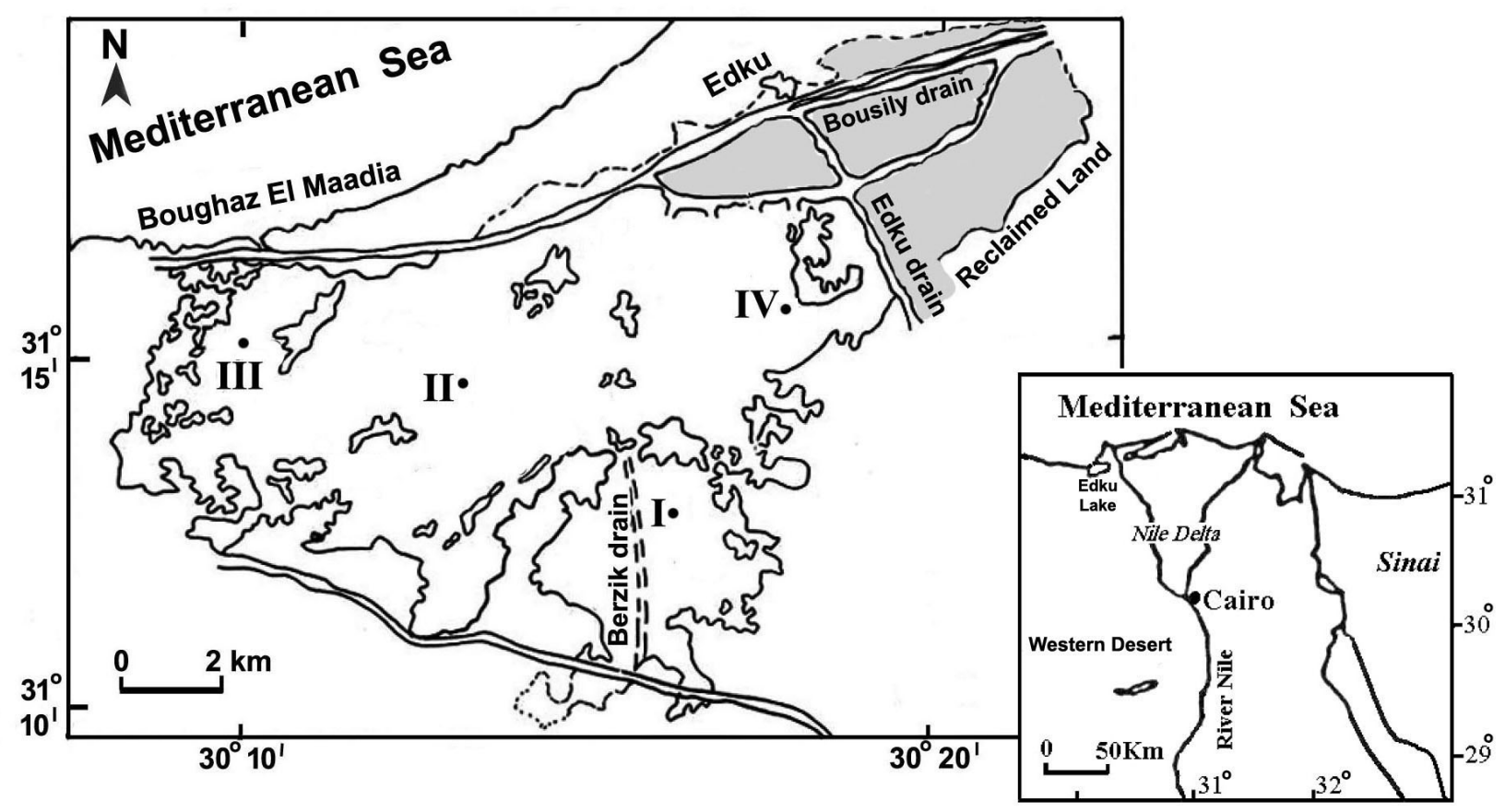

Figure 1. Location map showing the position of the studied cores in Lake Edku.

at least 500 diatom valves were counted. The relative frequencies of each species were expressed as a percentage of total diatom valves (\% TDV) counted in each sample. Diatoms were identified to the species level and their ecological interpretation were taken mainly from published literature (e.g., Hustedt 1957, 1930-1966; Ehrlich 1973, 1975; Ehrlich and Ortel 1979; Simonsen 1962, 1979; Krammer and Lange-Bertalot 1986 - 1991; Gasse 1986; Round et al. 1990; Foged 1980, 1993; Denys 1991-1992; Zong 1997). Salinity preferences were based on Hustedt (1957), Simonsen (1962) and Denys (1991-1992). Information on the ecology of the dominant diatom species is presented, and changes in diatom community composition are evaluated. The dominant species that have relative abundance over $5 \%$ of the total diatom valves in the examined samples were analyzed stratigraphically for each studied section.

Multivariate statistical analysis performed by the computer program Past (Hammer et al. 2001) was used to distinguish diatom ecological groups. Our calibration model included the diatom taxa that exceeded $3 \%$ in at least 5 samples of each core, and all samples containing diatoms were used as active samples. In order to investigate diatom assemblage patterns and the change in diatom composition, an indirect ordination technique of Detrended Correspondence Analysis (DCA) with detrending by segments and down-weighting of rare taxa was performed. Agglomerative Hierarchical Clustering process was based on Euclidean distance was carried out in order to group diatom taxa according to relative abundance data and to determine assemblage zones.

\section{Results and discussion}

Diatom examination of the studied four cores sediments led to identify 128 diatom species and varieties belonging to 42 genera. Of all recorded species, 64 taxa occurred regularly in the samples, while 26 of these species were distributed common or abundant. The remaining species occurred either infrequently or in very low relative abundance. The diatom assemblages of Edku Lake are dominated through most of the cores by salt tolerant, epiphytic, alkaliphilous taxa especially Cocconeis placentula (often over $40 \%$ of the total assemblage), associated with common occurrence of Epithemia sorex, Epithemia adnata and the benthic forms Navicula aegyptiaca, Campylodiscus biocostatus, Campylodiscus clypeus and Tryblionella granulata. The distribution pattern of the identified assemblages varies significantly between the studied cores and indicates changes in the floristic composition. Results of diatom analysis and the relative abundance of the dominant and sub-dominant taxa have been synthesized in the form of percentage diagrams (Figs. 4-7). The stratigraphic distribution patterns indicate different diatom ecozones for each studied core. As well as, the hierarchical, agglomerative cluster (Fig. 2) and Detrended Correspondence Analyses (DCA) (Fig. 3) 
distinguished six ecological diatom groups, which reflect distinctive environments and correlated well with the 


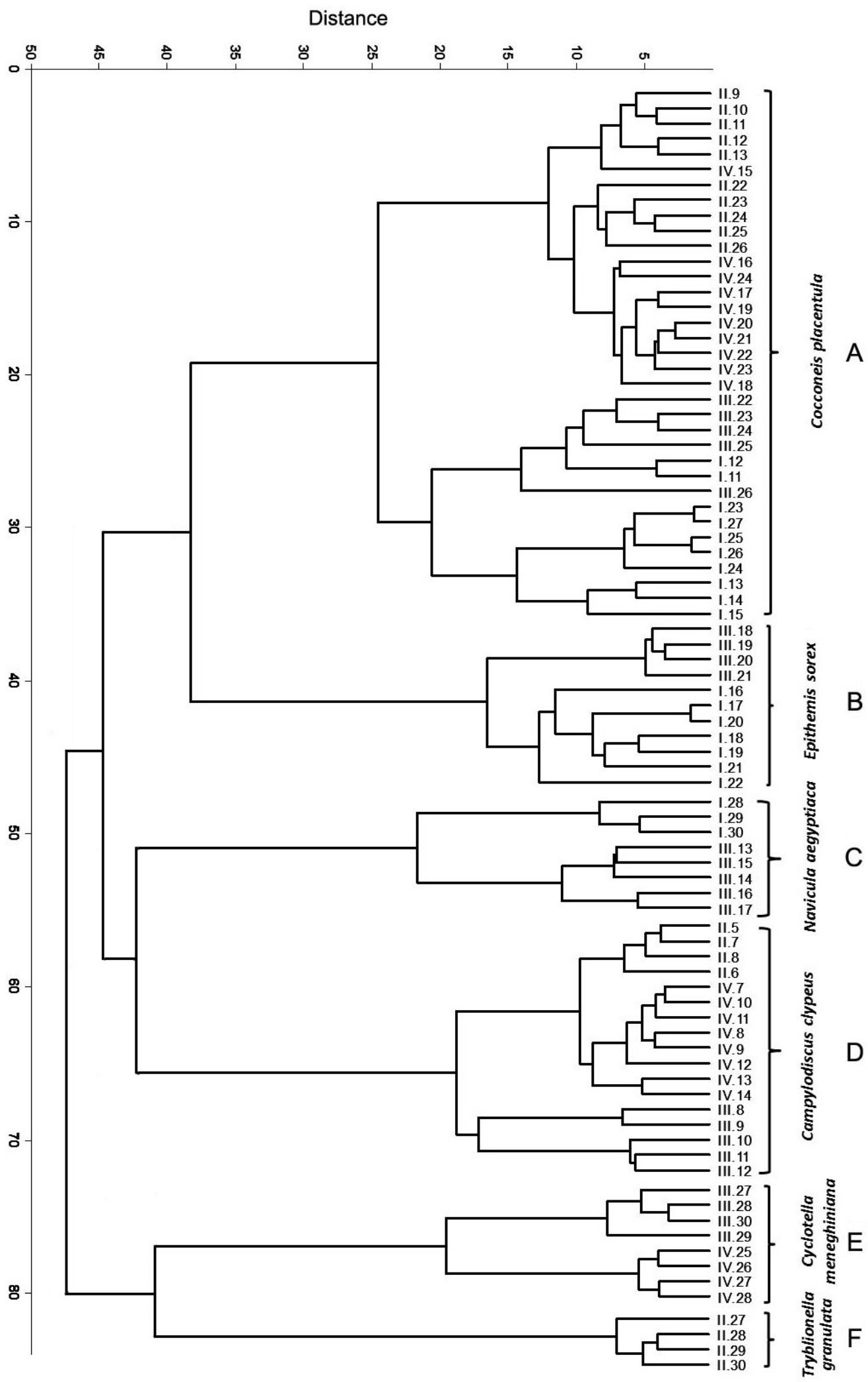

Figure 2. Cluster analysis of the examined samples based on the dominant and subdominant diatom taxa identified in the studied cores and showing the ecological diatom groups. 
stratigraphic zones. The results gained from the diatom ecological groups and zonations of the cores reflect changes in water salinity, lake level and trophic state of the lake, which in turn may related, at least indirectly, to climatic changes and anthropogenic effects.

Ecological Group A is an epiphytic assemblage dominated by Cocconeis placentula and its varieties, with relative abundance between 40 to $60 \%$ of the total assemblage. Sub-dominant taxa frequently includes Epithemia sorex, E. adnata, Gomphonema gracile, $G$. affine, Cymbella affinis, Rhopalodia gibba and tychoplanktonic Synedra ulna, with minor components of some benthic Navicula spp., Nitzschia spp. and planktonic Cyclotella taxa. The mesohalobous species are represented by sporadic occurrence of Campylodiscus echeneis, $C$. clypeus, Nitzschia obtusa and N. scalaris. This ecological group reflects shallow, eutrophic, slightly brackish environment with well-developed macrophyts. It was observed in most cores from Edku Lake (cores I, S. 11-15, 23-27; core II S.9-13, 22-26; core III, S.22-26; core IV, 1524).

Ecological Group B is distinguished by common abundance of epiphytic taxa. Epithemia sorex has high abundance that reaches about $30-45 \%$ of the total assemblage, and associated with common to frequently occurrence of Rhopalodia gibba, Epithemia adnata and Cocconeis placentula. Other epiphytic taxa such as Epithemia turgida, Gomphonema gracile, Gomphonema affine, Rhoicosphenia curvata, Rhopalodia rhopala, $R$. gibba and Rhopalodia acuminata occur sporadically. The planktonic taxa represented by Cyclotella meneghiniana, $C$. ocellata with some benthic species are distributed sporadically in this group. The diatom assemblage reflects a shallow, mesotrophic to eutrophic, freshwater environment with slightly increased alkalinity and salinity. This group was observed in the middle part of core I (sample 16-22; 0-30 cm) and core III (S. 18-21;0-15, 40 $\mathrm{cm})$.

Ecological Group C is dominated by brackish water diatoms. Navicula aegyptiaca has maximum abundance, varying between 34 and $45 \%$ of the total assemblage. The diatom association contains considerable abundances of such mesohalobous taxa as Anomoeoneis sphaerophora, Amphora commutata, Rhopalodia musculus and Amphora veneta. The assemblage denotes shallow, brackish water environment, with lowered lake level. It was observed at the topmost part of core I, sample 28-30 and middle part of core III, at samples 13-17.

Ecological Group D is distinguished by great abundance of benthic taxa rather than the epiphytic and planktonic forms. The brackish water species Campylodiscus clypeus was dominant, with relative frequency between $45-48 \%$ of the total assemblage. The association contains common to frequently occurrence Cocconeis placentula in companied with other mesohalobous taxa such a Campylodiscus echeneis,
Amphora commutata, Navicula aegyptiaca, Nitzschia obtuse, N. scalaris Rhopalodia musculus and Anomoeoneis sphaerophora. The freshwater taxa including both benthic and epiphytic forms such as Epithemia sorex, E. adnata, Synedra ulna and others Navicula spp., Nitzschia spp. are distributed scarcely. The assemblage is characteristic of shallow, brackish water environment with elevated salinity. It was observed at the basal part of core II (samples 5-8), core III (samples 8-12) and core IV (samples 7-14).

Ecological Group E is represented by abundance of the planktonic Cyclotella meneghiniana with relative frequency between 35 and $45 \%$ of the total assemblage and associated with frequently occurrence of Cyclotella atomus, Cyclotella ocellata. The association contains infrequent Cocconeis placentula, Synedra ulna, Epithemia sorex and limited Navicula aegyptiaca, Navicula spp., Nitzschia spp. and Tryblionella spp. The diatom assemblage reflects a shallow, mixed (freshwater-brackish) environment, with rising lake level. This group was observed at the topmost part of both cores III (27-30) and IV (25-28).

Ecological Group $F$ is a mixed assemblage that contains fairly common abundances of coastal polyhalobous taxa such as Tryblionella granulata, Grammatophora marina, associated with common to frequent occurrence of mesohalobous and salt-tolerant forms such as Hyalodiscus laevis, Diploneis bombus, D. didyma, Cyclotella meneghiniana, Cocconeis placentula, Rhopalodia musculus, Campylodiscus clypeus, C. echeneis, Nitzschia scalaris and $N$. obtuse. The freshwater taxa, Epithemia sorex, Rhopalodia gibba and Synedra ulna are sporadic. This diatom assemblage designates shallow, slightly alkaline mixed (marine - brackish) environment, with fluctuated lake level. This group was recorded only in the core II at the top most samples 27-30.

\section{Diatom stratigraphy and environmental interpretation}

Reconstruction of the environmental changes during the Late Holocene in Edku Lake is explained from the stratigraphic distribution pattern of the recorded diatom taxa in the studied cores, which led to classify each core into several zones. These zones are correlated well with the recognized ecological groups.

Core I: in southern part of the lake, is divided into four zones. The lowest core samples (1-10) are completely barren of diatoms. The first diatom zone I includes samples 11-15 (thick. $15 \mathrm{~cm}$ ), and characterized by diatom assemblage of ecological group A, which is dominant by Cocconeis placentula with relative abundance between 33 $50 \%$ of the total assemblage. This zone reflects shallow, eutrophic, slightly brackish environment, with predominance of macrophytes. The upper boundary of this zone is distinguished by a sudden decrease in the abundance of Cocconeis placentula and abrupt increase in abundance of Epithemia sorex through the second zone II, which represented by diatom assemblage of ecological group B. This second zone includes samples 16-22 (thick 


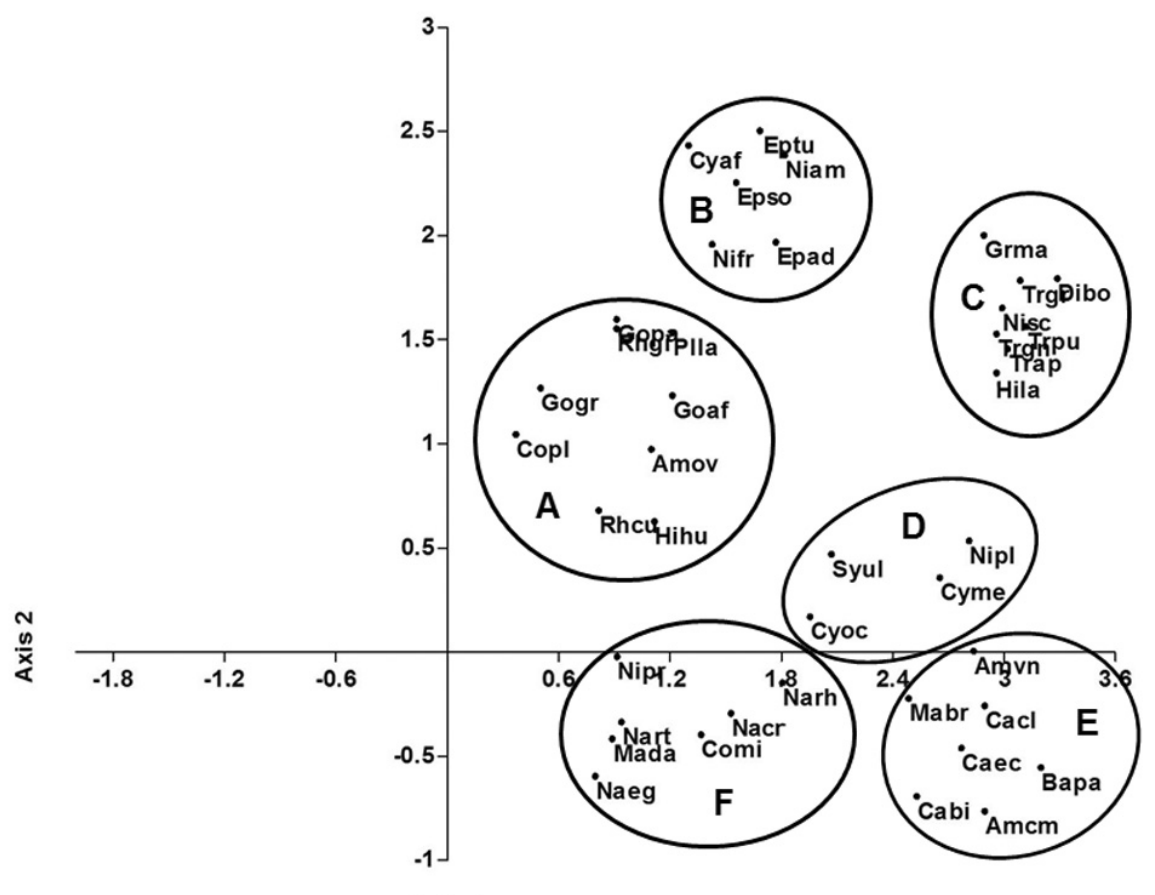

Axis 1

Fig. 3. Detrended Correspondence Analyses (DCA) biplot showing the dominant and subdominant diatom species scores, which distinguished six ecological groups

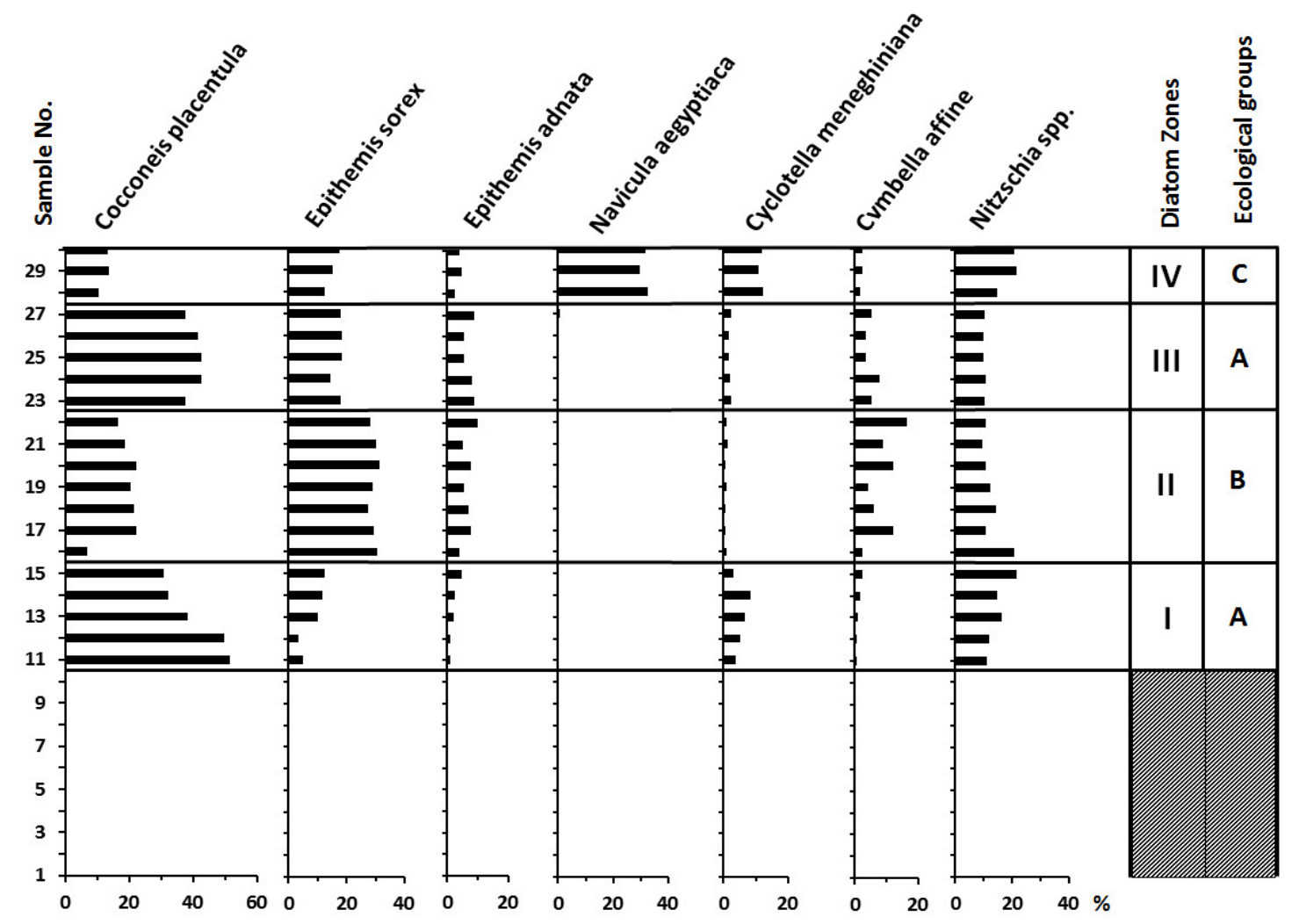

Figure 4. Diatom stratigraphy of core I showing the diatom zones correlated with ecological groups. 


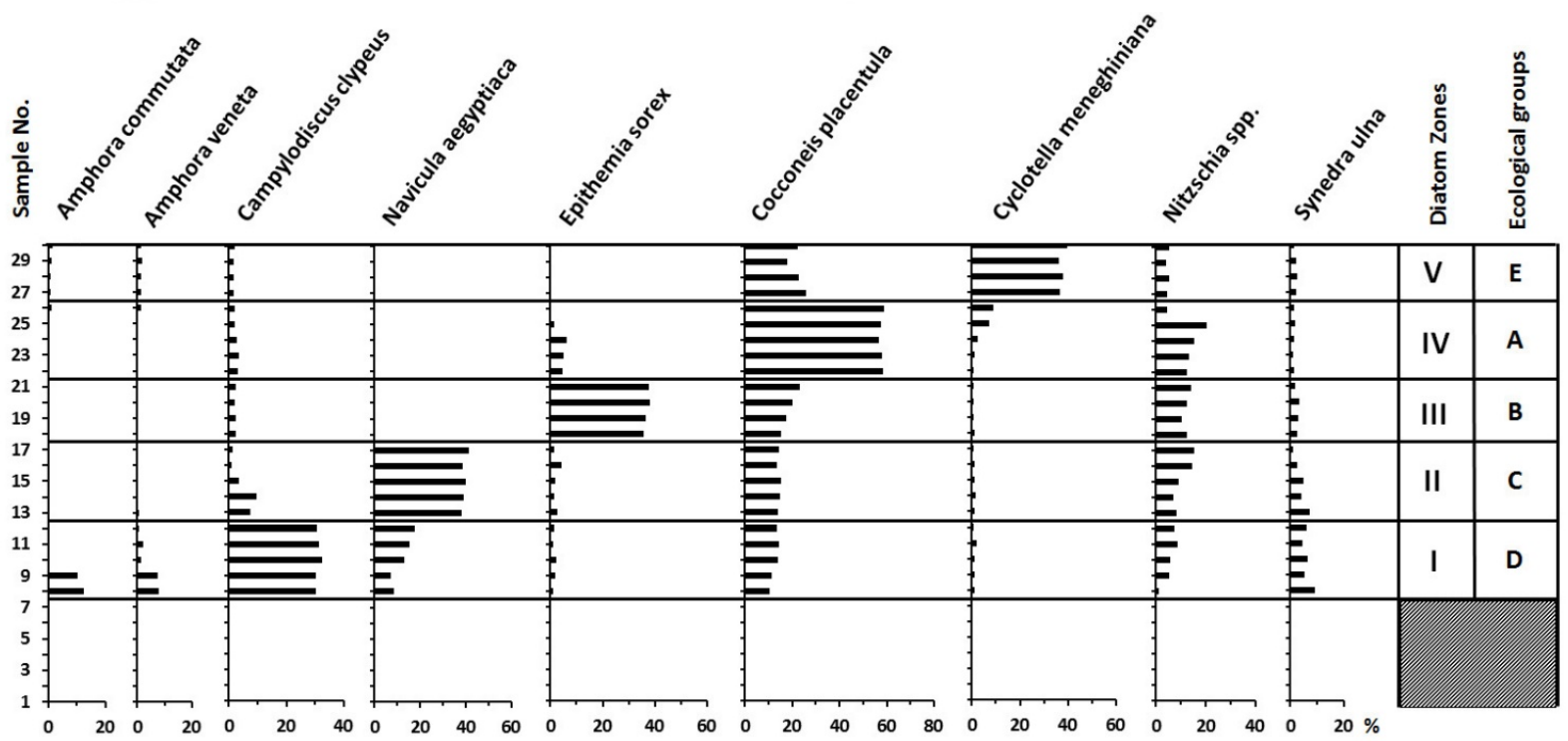

Figure 5. Diatom stratigraphy of core II showing the diatom zones correlated with ecological groups.

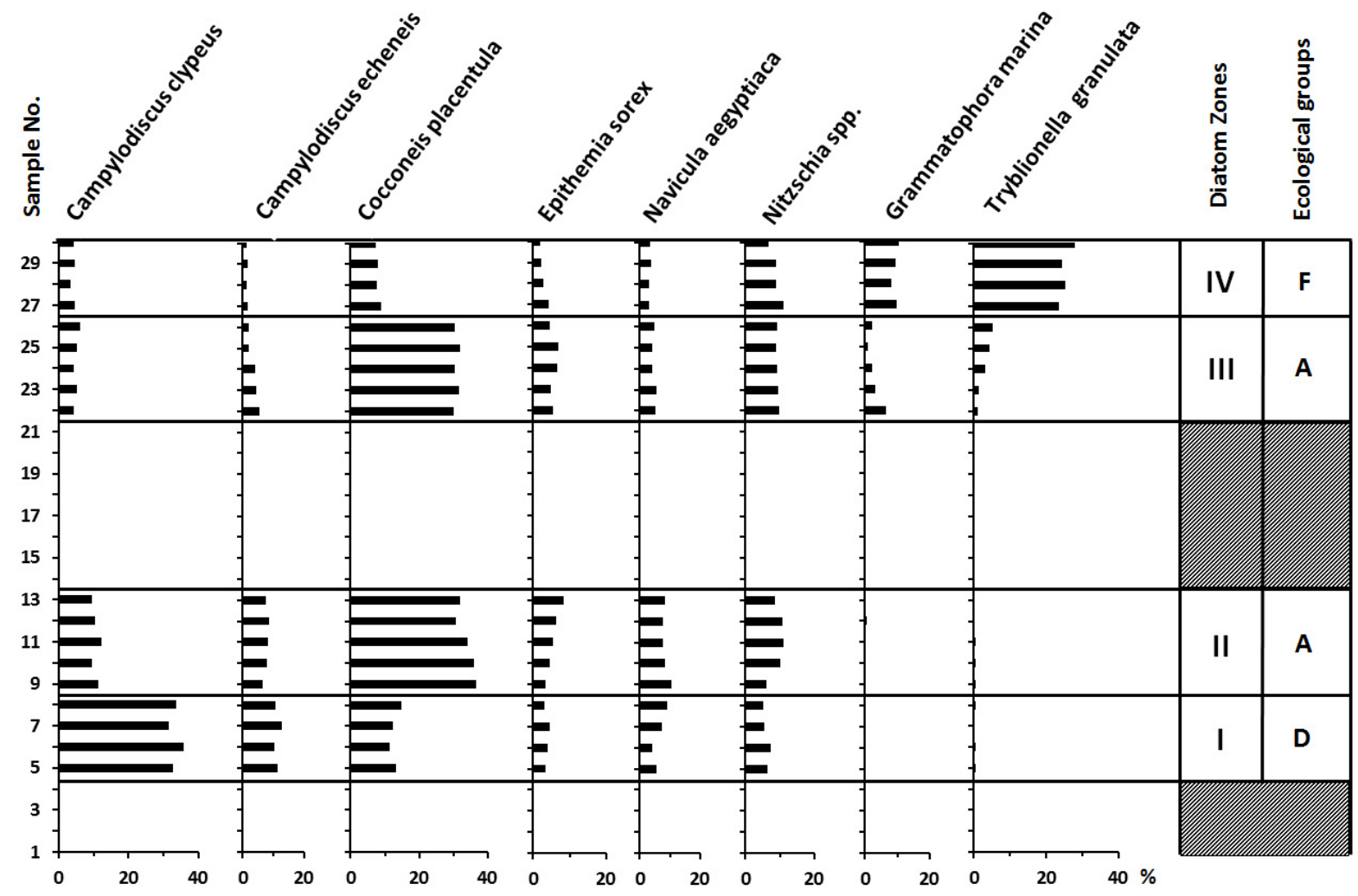

Figure 6. Diatom stratigraphy of core III showing the diatom zones correlated with ecological groups. 


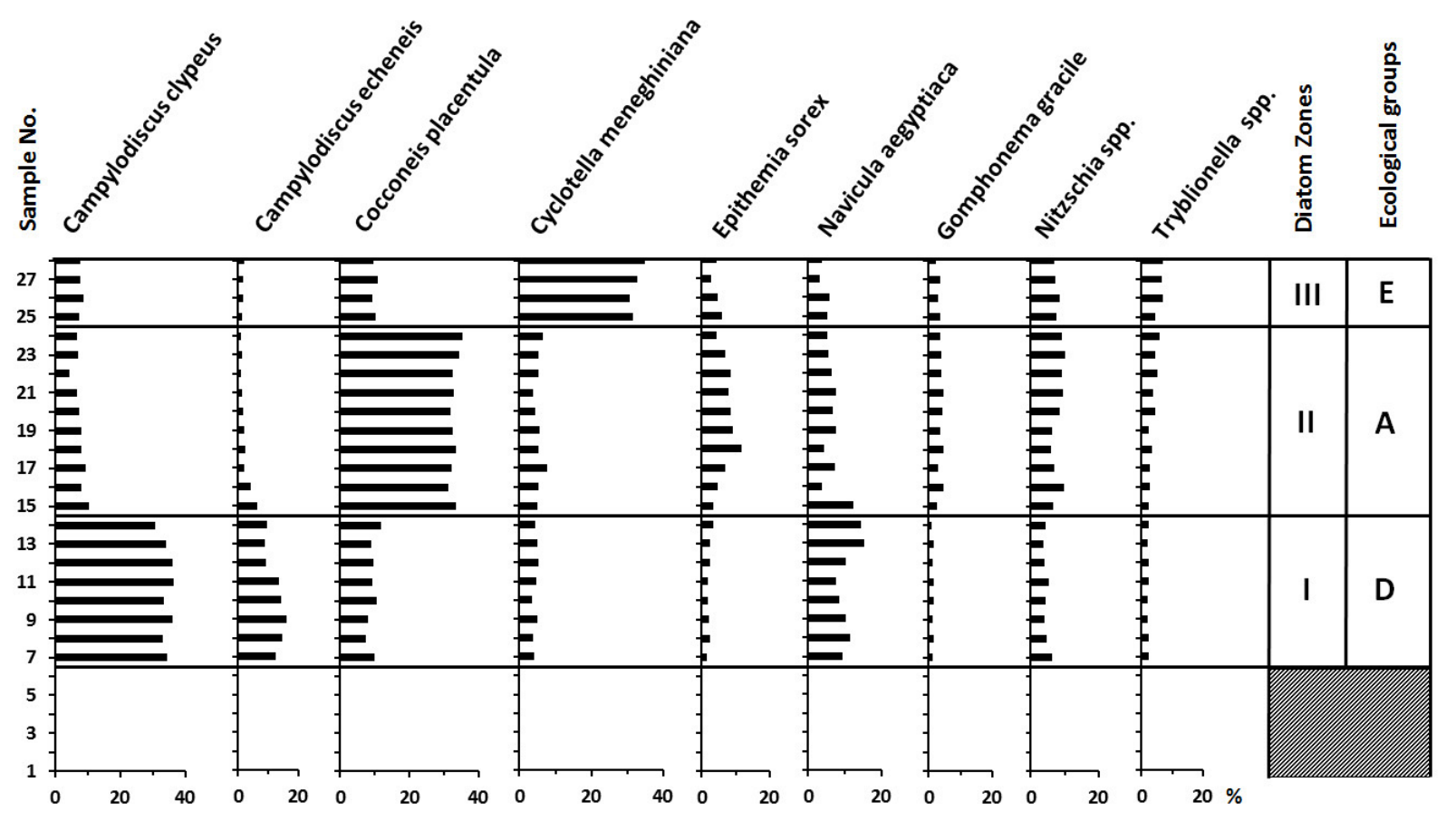

Figure 7. Diatom stratigraphy of core IV showing the diatom zones correlated with ecological groups.

$21 \mathrm{~cm}$ ), and its diatom assemblage denote to a shallow, eutrophic, freshwater environment with slightly increased alkalinity and salinity. Re-abundance of Ecological group A in the third zone III through the samples 23-27 (thick. $15 \mathrm{~cm}$ ), where Cocconeis placentula has maxima abundance with decreasing in Epithemia sorex, E. adnata, and the benthic forms of Nitzschia spp. Cymbella spp. and Navicula spp. Zone III reflects deposition in shallow, eutrophic, slightly alkaline freshwater environments with developed of macrophytes. The last zone IV contained the topmost recent samples $28-30$ (thick. $10 \mathrm{~cm}$ ), which is characterized by diatom assemblage of ecological group C. Navicula aegyptiaca is the dominant taxon with frequently occurrence of planktonic Cyclotella meneghiniana associated with some epiphytic and benthic taxa. This zone indicates deposition in shallow, alkaline, mesotrophic, brackish water environment, with lowered lake level and impacts of human activity.

Core II: is located at the middle part of the lake and it is divided into five diatom zones. The basal part of the core (samples 1-7) is devoid of diatom taxa. This is followed by zone I that comprises samples 8-12 and characterized by first high abundance of brackish benthic Campylodiscus clypeus associated with frequently occurrence of other mesohalobous taxa of ecological group $\mathrm{D}$. The diatom assemblage denotes shallow, alkaline, brackish water conditions during the time of deposition. This type of environment is continued through the next zone II (sample 13-17) that represented by abundance of diatom assemblage of ecological group C. Campylodiscus clypeus is decreased abruptly in relative abundance and replaced by Navicula aegyptiaca that has maxima abundance in this zone. The lake water conditions changes into alkaline, freshwater environment in the next zone III (samples 1821 ), where the diatom assemblage of ecological group B is prevailed. The abundance of Navicula aegyptiaca of previous zone is disappeared and replaced by high abundance of Epithemia sorex accompanied by frequently occurrence of several epiphytic taxa of group B. The upper boundary of zone III is represented by distinct decreasing in abundance of Epithemia sorex that followed by great abundance of epiphytic taxon Cocconeis placentula with relative frequency reached to $60 \%$ of the total assemblage in the zone IV. In this zone the diatom assemblage of ecological group A is recorded and shallow, eutrophic, slightly brackish water conditions with abundance of aquatic vegetation at the time of deposition. The end zone $\mathrm{V}$ contained the topmost recent samples 27-30, which characterized by great abundance of planktonic Cyclotella meneghiniana. The diatom assemblage of ecological group E distinguishes this zone and reflects a shallow, mixed (freshwater-brackish) environment, with rising lake level.

Core III: in the northwestern part of the lake is divided into four diatom zones interrupted with unit devoid of diatoms. The lowest core samples 1-4 are completely barren of diatoms. The first zone I contains samples 5-8 (thick. $12 \mathrm{~cm}$ ) starts with increased in abundance of Campylodiscus clypeus with frequently occurrence of 
Campylodiscus echeneis, Cocconeis placentula and low abundance of Epithemia spp., Nitzschia spp. Navicula spp. This assemblage belongs to ecological diatom group D, which reflects shallow, brackish water environment with elevated salinity. The second diatom zone II contained samples 9-13, which characterized by dominance of ecological diatom group A. Cocconeis placentula has maxima abundance which reflects shallow, eutrophic, slightly alkaline freshwater environment with predominance of macrophytes. This zone is overlain by unite included samples 14-21 (thick. $20 \mathrm{~cm}$ ) devoid of diatoms. Ecological diatom group $\mathrm{A}$ is appeared again in the next zone III (samples 22-26), which means continuation of shallow, freshwater environment. The fourth zone comprised the topmost samples 27-30, which represented by dominance of coastal marine taxa Tryblionella granulate, Grammatophora marina, Diploneis bombus accompanied by some brackish and limited occurrence of freshwater taxa. The diatom assemblage belongs to ecological group $\mathrm{F}$, which reflects the impact of the Mediterranean Sea and intrusion of the marine water into the lake during rising sea level in the recent time.

Core IV: is situated in the eastern part of the lake and is divided into three marked zones. As the previous cores, the basal part comprised samples 1-6 is devoid of diatoms. This unit is followed by zone I that distinguished by first great abundance of benthic mesohalobous Campylodiscus clypeus accompanied with frequently appearance of many mesohalobous taxa. The diatom assemblage of ecological group D characteristic this zone and reflects shallow, alkaline, brackish water environment with elevated salinity. The next zone II (samples 15-24) is represented by noticeable decrease in abundance of Campylodiscus clypeus with high abundance of epiphytic taxon Cocconeis placentula that distinguishes the ecological group A. The assemblage denotes a shallow, eutrophic, slightly brackish to freshwater conditions with abundance of aquatic vegetation in this part of the lake. There is an observed change in abundance of diatom taxa through the next zone III that included the topmost recent samples 25-28. Cocconeis placentula is decreased in relative abundance and replaced by abruptly increased in abundance of planktonic taxon Cyclotella meneghiniana. The diatom assemblage of ecological group E characteristic this zone, which reflects shallow, slightly alkaline, slightly brackish to freshwater environment with relatively rising lake level during the recent time.

\section{Conclusions}

Paleoenvironmental changes in the northern Egypt through the Late Holocene have been reconstructed from the preserved diatom assemblages in the Edku lake sediments. The general distribution pattern and diatom composition across the cores reflect changes in the water salinity, lake level and alkalinity characters, which are may related to at least indirectly to climatic changes, eustatic sea-level fluctuations and human activities during the Late
Holocene. The disappearance of diatoms in the bottom sediments of all cores may be due to dilution of diatom frustules by the clay sediments (Zalat and Servant 2007). DCA and cluster analyses explained six distinct diatom ecological groups, each of which reflects a certain environment. The diatom assemblages in the lake sediments show a clear succession from shallow muddy, highly brackish conditions dominated by a benthic mesohalobous assemblage of ecological group D in the lower part of cores II, III and IV, to eutrophic, alkaline, slightly brackish water environment dominated by epiphytic diatoms in the middle parts of cores that located in the south, east and west of the lake. This is due to the predominance of salt-tolerant epiphytic taxa; particularly Cocconeis placentula throughout the assemblage of ecological group A accompanied with common occurrence of Epithemia sorex, E. adnata, Gomphonema gracile, Rhopalodia gibba that characteristic ecological group B. This reflects the abundance of aquatic vegetation in slightly brackish water conditions during the time of deposition.

Furthermore, the diatom assemblages in the upper 10$15 \mathrm{~cm}$ sediments were diverse and contained common eutrophic, alkaline mesohalobous and salt-tolerant benthic taxa, of ecological group $\mathrm{C}$ in core I at the southern part of the lake. However, the topmost recent samples of cores III and IV that located in the middle and the eastern part of the lake were dominant by planktonic fresh to slightly brackish water taxa Cyclotella meneghiniana indicating slightly rising lake level with freshwater drainage impact from the drains. In contrary, the upper 10-12 cm sediments of northwestern core II is characterized by diverse mixed assemblage of coastal marine polyhalobous and brackish water taxa of ecological group $\mathrm{F}$ including Tryblionella granulate, Grammatophora marine and Hyalodiscus laevis. The occurrence of coastal marine species in this area indicates the influence of seasonal marine invasion to the lake in recent times. Generally, a slight decline in salinity level is indicated, and most of the recent decades have experienced fresh to slightly brackish waters conditions with an abundance of aquatic macrophytes. The freshwater discharge from drains has allowed the spread of aquatic plants that led to abundance of epiphytic diatom taxa in the most of the studied cores samples. Occasionally, the salinity increased slightly at the northwestern area due to marine incursions during rising sea level. Overall, the marked changes and proportional shifts between the ecological diatom groups in the cores sections of the lake display that there were a number of oscillations between fresh and saline conditions in shallow lake, and hence changes in the environment and climate.

\section{References}

Abdel-Moati, A.R. and El-Sammak, A.A. (1996). Manmade impact on the geochemistry of the Nile delta lakes. A study of metal concentrations in sediment. J. Water Air Soil Pollut. 90: 413-429. 
Badr, N.B.E. and Hussein, M.M.A. (2010). An input/output flux model of total phosphorus in Lake Edku, a northern eutrophic Nile Delta Lake, Global J. Environ. Res., 4 (2): 64-75.

Banoub, M.W. (1979). The salt regime of Lake Idku (Egypt) before and after the construction of Aswan's high dam. Arch. Hydrobiol. 83: 392-399

Banoub, M.W. (1983). Nutrients salts of Idku (Egypt) before and after the construction of the Aswan high dam. (1958-1969). Rapp. Comm. Int. Mer. Médit. 28: 181-183.

Bracco, R., Inda, H., del Puerto, L., Castiñeira, C., Sprechmann, P. and García-Rodríguez, F. (2005). Relationships between Holocene sea-level variations, trophic development, and climatic change in Negra Lagoon, Southern Uruguay. J. Paleolimnol. 33: 253263.

Bradbury, J.P., Colman, S.M. and Dean, W.E. (2004). Limnological and Climatic Environments at Upper Klamath Lake, Oregon during the past 45000 years. J. Paleolimnol. 31: 167-188.

Denys, L. (1991/1992). A check-list of the diatoms in the Holocene deposits of the western Belgian coastal plain with a survey of their apparent ecological requirements. I. Introduction, ecological code and complete list. Professional Paper 1991/2 No. 246, Ministerie van Economische Zaken, Jennerstraat 13: $10-40$.

Edlund, G. and Carman, R. (2001). Distribution and diagenesis of organic and inorganic phosphorus in sediments of the Baltic proper, Chemosphere 45 (67): $1053-1061$.

Ehrlich, A. (1973). Quaternary Diatoms of the Hula Basin (northern Israel). Bull. Geol. Surv. Isr. 58: 1-39.

Ehrlich, A. (1975). The Diatoms from the surface sediments of the Bardawil Lagoon (Northern Sinai)Paleoecological significance. Nova Hedwigia 53: 253-277.

Ehrlich, A. and Ortel, R. (1979). The Influence of salinity on the Benthic Diatoms Communities of the Lower Jordan River. Nova Hedwigia 64: 325-336.

Foged, N. (1980). Diatoms in Egypt. Nova Hedwigia 33: 629-707.

Foged, N. (1993). Some diatoms from Siberia, especially from Lake Baikal. Diatom Res. 8: 231-279.

Fritz, S.C., Cumming, B.R., Gasse, F. and Laird, K.L. (1999). Diatoms as indicators of hydrologic and climatic change in saline lakes. In: Stoermer E.F. and
Smol J.P. (eds.), The Diatoms: applications for the environmental and earth sciences, CUP, Cambridge: 41-72.

Gasse, F. (1986). East African diatoms. Taxonomy, ecological distribution. Biblioth. Diatomol. 2: 1-201.

Gharib, S.M. (1999). Phytoplankton studies in Lake Edku and adjacent waters (Egypt). Egypt J. Aquat. Biol. Fish. 3: 1-23.

Gharib, S.M. and Soliman, A.M. (1998). Some water characteristics and Phyto-Zooplankton relationship in Lake Edku (Egypt) and adjacent sea. Bull. Fac. Sci. Alex. Uni. 38: 25-44.

Hammer, Ø. Harper, D.A.T. and Ryan, P.D. (2001). PAST: paleontological statistics software package for education and data analysis. - Palaeontol. Electronica. 4.

Hemeda, H. (1988). The dynamics of nutrients between water and sediments in Lake Edku. M.Sc. thesis, University of Alexandria, Alexandria, Egypt.

Hustedt, F. (1930-1966). Die Kieselalgen. In Rabenhorst L. (ed.), Kryptogamenflora von Deutschland, Oesterreich und der Schweiz, Akad. Verlagsgesel. Leipzig, 1: 1-920, 2: 1-845, 3: 1-816.

Hustedt, F. 1957. Die Diatomeenflora des Fluss-systems der Weser im Gebiet der Hansestadt Bremen. Abhandl. Naturwiss. Ver. Bremen 34: 181-440.

Ibrahim, M.K.H. (1994). Geochemical cycle of phosphorous in Lake Edku. M.Sc. thesis, Alexandria Univ., Alexandria, Egypt.

Khalil, M. Kh. (2007). The fractional composition of phosphorus in Edku lagoon and adjacent marine sediments, Egypt. JKAU: Mar. Sci., 19: 149-166.

Khalil, M.T., Shakir, S.H., Saad, A.A., El Shabrawy, G.M. and Hassan, M.M. (2008). Physico -chemical environment of Lake Edku, Egypt. Egypt. J. Aquat. Biol. \& Fish., 12(2) : $119-132$

Kim, L.H., Choi, E. and Michael, K. S. (2003). Sediment characteristics, phosphorus types and phosphorus release rates between river and lake sediments, Chemosphere, 50 (1): 53-61.

Kinawy, S.M.A. (1974). Hydrography and nutrient salts in the water of Lake Edku, Egypt. M.Sc. Thesis. Fac. Sci., Alex. Univ., 203pp.

Korhola, A., Weckström, J., Holmström, L. and Erästö, P. (2000). A quantitative climatic record from diatoms in northern Fennoscandia. Quaternary Res. 54: 284294. 
Krammer, K. and Lange-Bertalot, H. (1986-1991). Bacillariophyceae. In: Ettl H., Gerloff J., Heynig H. and Mollenhauer D. (eds.), Süsswasserflora von Mitteleuropa, Vol. 2 (1), 876 pp., 2 (2), 596 pp., 2 (3), 576 pp., 2 (4), 437 pp., Gustav Fischer Verlag, Stuttgart/Jena.

Kuwae, M., Yoshikawa, S., Tsugeki, N. and Inouchi, Y. (2004). Reconstruction of a climate record for the past $140 \mathrm{kyr}$ based on diatom valve flux data from Lake Biwa, Japan. J. Paleolimnol. 32: 19-39.

Laird, K.R., Kingsbury, M.V., Lewis, C.F.M. and Cumming, B.F. (2011). Diatom inferred depth models in 8 Canadian boreal lakes: inferred changes in the benthic:planktonic depth boundary and implication for assessment of past droughts. - Quat. Sci. Rev. 30: 1201-1217.

Moser, K.A., Korhola, A., Weckström, J., Blom, T., Pienitz, R., Smol, J.P., Douglas, M.S.V. and Hay, M.B. (2000). Paleohydrology inferred from diatoms in northern latitude regions. - J. Paleolimnol. 24: 93107.

Moufaddal, W., El-Sayed, E. and Deghady E. (2008). Updating morphometric and edaphic information of lakes Edku and Burullus, Northern Egypt, with the aid of satellite remote sensing, Egypt. J. Aquat. Res., 34 (4): 291-310.

Moussa, A.A. and El-Sayed, M.A. (1990). Geochemistry of $\mathrm{Fe}, \mathrm{Mn}, \mathrm{Zn}, \mathrm{Cu}, \mathrm{Pb}$ and $\mathrm{Cd}$ in sediment cores from Lake Edku. Rapp. Comm. Int. Mer. Medit. 32 (1): $67 p$.

Nour El-Din, N.M. (2000). Study of the chemical composition of suspended matter and adsorbed elements in Lake Edku. M.Sc. Thesis. Fac. Sci. Alex. Uni., 219 p.

Okbah, M.A. and El-Gohary, S.El. (2002). Physical and chemical characteristics of Lake Edku Water, Egypt. Medit. Mar. Sci. 3/2: 27-39.

Ramdani, M., Flower, R.J., Elkhiati, N., Kraïem, M.M., Fathi, A.A., Hilary, H. Birks, H.H. and Patrick, S.T. (2001). North African wetland lakes: characterization of nine sites included in the CASSARINA Project. Aquat. Ecol. 35: 281-302.

Round, F.E., Crawford, R.M. and Mann, D. G. (1990). The diatoms. Biology and morphology of the genera. Cambridge University Press, Cambridge, 747 pp.

Saad, M.A.H. (1976). Some limnological investigations of lake Idku, Egypt. Arch. Hydrobiol. 77: 411-430.
Saad, M.A.H. (1978a). A study on the mixed waters between Lake Idku and the Mediterranean Sea. Bull. Off. Natl. Pêch. Tunisie 2: 347-354.

Saad, M.A.H. (1978b). Distribution of phosphate, nitrite and silicate in Lake Idku, Egypt. Verh. Int. Verein. Limnol. 20: 1124-1130.

Saad, M.A.H. (1988). Studies on the core sediments of Lake Edku. Egypt. Rapp. Comm. Int. Mer. Medit., 31-32.

Shakweer, L.M. (2006). Impacts of drainage water discharge on the water chemistry of lake edku. Egyptian journal of aquatic research. 32 (1): 264-282.

Shakweer, L.M., El-Ebiary, E.H. and Zaki, M.A. (1998). Comparative study on the major biochemical constituents in the muscles of Mugil Cephalus inhabiting the Mediterranean water, the northern delta lakes and fish farms of Egypt. Bull. Natl. Inst. Oceanogr. Fish. (Egypt) 24: 79-101.

Shata, M.A. (2000). Lithifacies characteristics of subsurface sediments of Lake Edku, Bull. NIOF, 26: 27-42.

Shridah, M.M.A. (1992). Recent observations on some hydrographic and chemical aspects of Lake Edku waters. Egypt. Bull. High Inst. Public Health XXII (1): 185-201.

Simonsen, R. (1962). Untersuchungen zur Systematik und Okologie der Boden-diatomeen der westlichen Ostsee. Inter. Rev. ges. Hydrobiol. 1: 1-144.

Simonse, R. (1979). The diatom system: Ideas on Phylogeny. Bacillaria 2: 9-72.

Smol, J.P. and Stoermer, E.F. (2010). The Diatoms: Applications for the Environmental and Earth Sciences. - 667 pp., Cambridge University Press, Cambridge.

Soliman, A.M. (1983). Quantitative and qualitative studies of the plankton in Lake Edku in relation to the local environmental conditions and to fish food. M.Sc. Thesis, Alexandria University, Egypt, 220 pp.

Stager, J.C., Ryves, D., Cumming, B.F., Meeker, L.D. and Beer, J. (2005). Solar variability and the levels of Lake Victoria, East Africa, during the last millennium. J. Paleolimnol. 33: 243-251.

Wolin, J.A. and Stone, J.R. (2010). Diatoms as indicators of water-level change in fresh-water lakes. - In: Smol, J.P. \& Stoermer, E.F. (eds): The Diatoms: Applications for the Environmental and Earth Sciences 2nd edition. - pp. 174-185, Cambridge University Press, Cambridge. 
Yang, J.R. and Duthie, H.C. (1995). Regression and weighted averaging models relating surficial sedimentary diatom assemblages to water depth in Lake Ontario. - J. Great Lakes Res. 21: 84-94.

Zaghloul, F.A. and N.R. Hussein, (2000). Impact of pollution on phytoplankton community structure in Lake Edku, Egypt. Bulletin of National Institue of Oceanography and. Fisheries, Egypt, 26: 297-318.

Zalat, A.A. (2002). Paleoecological and environmental history of Lake Mariut, Egypt, by means of diatoms. Diatom Res., 17: 167-191.

Zalat, A.A. and Servant Vildary, S. (2005). Distribution of diatom assemblages and their relationship to environmental variables in the surface sediments of three northern Egyptian lakes. J. Paleolimnol. 34: 159-174.

Zalat, A.A. and Servant-Vildary, S. (2007). Environmental change in Northern Egyptian Delta lakes during the Late Holocene, based on diatom analysis. Journal of Paleolimnology 37: 273-299.

Zalat, A.A. (2015). Holocene diatom assemblages and their palaeoenvironmental interpretations in Fayoum depression, Western Desert, Egypt. Quaternary International 369: 86-98

Zong, Y. (1997). Implications of Paralia sulcata abundance in Scottish isolation basins. Diatom Res. 12: $125-150$.

\section{التحليل الدياتومى لرواسب بحيرة إدكو لتقييم التغيرات البيئية خلال الهولوسين العلوى فى شمال مصر عبل الفتاح على زلط - حزة مصطفى ظليل - على سليمان على - سهام عبدالرحن النجار قسم الجيولوجيا ـ كلية العلوم - جامعة طنطا}

تتناول الدراسة التحليل الدياتومى للرواسب القاعية لبحيرة إدكو وذلك لتقييم التاريخ البيئى خلال زمن الهولوسين العلوى. لقد تم التعرف على 128 نوع من الدياتومات من 118 عينة ممثلة من أربعة أبار قصيرة أخذت من أماكن مختلفة من البحيرة تمثل بيئات

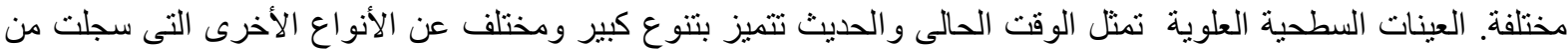
الرواسب القديمة. الدراسة المستفيضة والدقيقة أوضحت أن هناك إختلاف فى تكوين وتوزيع الدياتومات بين الأماكن المدروسة.

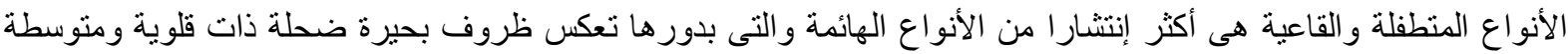
الملوحة وغنية بالمادة النبتريتية خلا زمن زمن الترسيب. التحليل الأحصائى استخدم لتميز المجموعات البيئية من الدياتومات. النتائج أوضحت وجود ستة مجموعات بيئية تعكس تغيرات فى نقاء المياه، والملوحة، و القلوية، و المادة النيتريتية وكذللك منسوب مبنة مياه

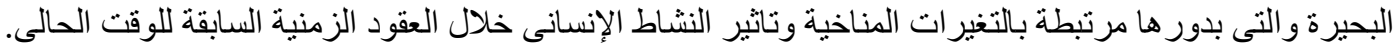

